\title{
Anatomy of spinal nerves in the first Turkish illustrated anatomy handwritten textbook
}

\author{
Murat Çetkin $^{1}$ • Mustafa Orhan ${ }^{1}$ • İlhan Bahși ${ }^{1}$ • Begümhan Turhan ${ }^{2}$
}

Received: 26 May 2016 / Accepted: 30 May 2016/Published online: 10 June 2016

(C) Springer-Verlag Berlin Heidelberg 2016

"Teşrih-ül Ebdan ve Tercümânı Kıbale-i Feylesûfan" is the first handwritten anatomy textbook with illustrations written in Turkish in 17th century by Şemseddîn-i İtâkî. "Teşrih" has different meanings such as anatomy, skeleton, and cutting a corpse into pieces [1]. "Teşrih-ül Ebdan ve Tercümânı Kıbale$i$ Feylesuffan " means dissection of the body and scholars' birth knowledge [2]. Since this is the first handwritten textbook in Turkish, it has great importance in the development of medicine in Ottoman Empire. This book was written while Grand Vizier Recep Pasha was in power, and it was dedicated to the Sultan of that period, Murat the IVth [3, 4]. It is thought that the book was written in 1632 [4-7].

Şemseddîn-i İtâkî was born in Shirvan (North Azerbaijan) in 1570s. Șemseddîn-i İtâkî was interested in mathematics, philosophy, medicine, hadith, cannon law, logic, and astronomy [4, 7]. İtâkî suffered hardships because of the wars and internal conflicts in Shirvan. He lost a lot of his family, and he had to leave Shirvan in 1604 when it was annexed by Persia [8]. After İtâkî left his homeland, he travelled to several countries for a long time but he did not receive much appreciation $[4,8]$. He arrived in Istanbul during the reign of Sultan Murad the IVth (1623-1640) and was introduced to Sadrazam (Grand Vizier) Recep Pasha. He was given the academic title "Haremeyn Payesi" by the Grand Vizier. He published his book with the help of Recep Pasha. In the introduction of

İlhan Bahși

dr.ilhanbahsi@gmail.com

1 Department of Anatomy, Faculty of Medicine, Gaziantep University, TR-27310 Gaziantep, Turkey

2 Department of Physiotherapy and Rehabilitation, Faculty of Health Sciences, Hasan Kalyoncu University, 27100 Gaziantep, Turkey the book, İtâkî acknowledges the contributions of the Grand Vizier [4, 7].

Not many textbooks about anatomy existed in the Islamic World and the Ottoman Empire until İtâkî's book [9]. In other medical textbooks, anatomy occupies only a few pages in different sections [4]. İtâkর̂i's book is a pioneer in its area as it is written in Turkish, and it is supported with illustrations [4]. In addition to Turkish, the book contains mostly Arabic and rarely Persian terms as well $[4,6,7]$. Some editions of this book which was written in the 17 th century were reprinted in the 18th century. Seven different editions are known today [4].

The book contains illustrations similar to Ahmed İbn Mansur's (14th century) book called Teşrih-i Ebdan. Some of the content was quoted from Avicenna's Canon Medicinae and İbn Nafis's Şerh-i Teşrihül Kanun. In addition to these illustrations, illustrations from other European based works like Andreas Vesalius's De Humani Corporis Fabrica also exist. Some of the illustrations were drawn by the author himself. These illustrations were drawn by the author himself usually depict the nervous system $[3,4,6,10]$.

The purpose of this study is to analyze the anatomy of the spinal nerves as stated in the book "Teşrih-ül Ebdan ve Tercümânı Kıbale-i Feylesûfan" written in the Ottoman Period, to evaluate the knowledge level about spinal nerve anatomy in 17 th century and compare that knowledge with current knowledge of anatomy.

In this study, Şemseddîn-i İtâkî̀'s illustrated anatomy book by Esin Kâhya which is the translation of "Teşrih-ül Ebdan ve Tercümânı Kıbale-i Feylesûfan" from the Ottoman alphabet into the Latin alphabet was evaluated. All of the sections of the book, especially the sections about spinal nerves, were analyzed in detail. This information was compared to our current knowledge; thus, its accuracy was inspected.

In the book, general information about the nervous system was provided in the anatomy of the nerves. Then, the cranial 
and spinal nerves were explained. İtâkî stated the following when he defined the nervous system "God, separated the spinal cord from the brain and made the spinal cord the caliph of the brain." With this statement, İtâkî summaries a major topic with a striking sentence. Spinal cord is considered as a lower center than the brain, and it is controlled by the brain when needed. Thus, İtâkîi’s definition is correct. He divided the nerves into sensory and motor nerves. This definition is consistent with our current knowledge. He claimed that sensory nerves are rapid and soft while the motor nerves are firm and powerful. The author wrote that if the nerves were not present, muscles would have been soft. He told that for the maintenance of muscle tone, nervous innervations are needed. $\mathrm{He}$ also defined the flaccid paralysis when this innervation is absent. He claimed that without the presence of nerves, muscles can be cut easily by stone or solid objects. This knowledge is not compatible with our current knowledge.

The internal organs like the liver, kidneys, and spleen that do not have sensory nerves within them. These organs are defined to be covered by a membrane which allows for the transmission of sensory information by the embedded nerves. In the pathological states of this membrane, some reactions will occur with the help of these nerves. With our current knowledge, we know that internal organs like the liver, kidneys, and spleen possess tunica serosa and autonomic innervations but İtâkî defined this information in an incomplete way.

\section{Spinal nerves}

In the book, spinal nerves are classified as nerves emerging from the vertebral column from the neck, back, sacrum, and coccyx.

\section{Cervical spinal nerves}

İtâkî defined that eight couples of spinal nerves in the neck region, and he explained each one separately. He emphasized that each nerve left between two vertebrae.

The first cervical spinal nerve was thinner than the rest of the cervical spinal nerves, and it could not reach whole of the head.

The second cervical spinal nerve exists between the first and second vertebrae and travels upward in a curved course until the head and spreads into the skin around the ear. Parts of this nerve travels to the muscles located at the back side of the neck.

The third cervical spinal nerve exists between the second and the third vertebrae and divides into two. One of the branches from this nerve innervated the muscle that rotated the neck while the other one moved to the spinous process of the vertebrae and joined a ligament. Then, it moved to the ear area, and this nerve gave power to muscles of the face and the temples. Its second branch went to the cheek reaching the flat muscle. While defining the third cervical spinal nerve, İtâkî defined the functions of this muscle in animals as well.

The fourth cervical spinal nerve came out from the hole between the third and fourth vertebrae by separating into two branches. The anterior branch united with a branch from the fifth cervical spinal nerve and constituted a quite small branch. The posterior branch is larger, and it moved toward the head. It rests between the spinous process of the vertebrae and the muscles. Then, the final branches from this second branch spread between the head and the neck. The distribution area was part of the face and the muscles of the vertebrae. He added that this branch move to the ear in the animals.

The fifth cervical spinal nerve comes out from the hole between the fourth and fifth vertebrae by separating into two branches. Anterior branch moves to the muscles of the shoulder. Some parts of this nerve innervates the flat muscle in the face and to the muscle that flexing the head. The second branch of the fifth cervical spinal nerve merges with some of the fibers of the sixth and seventh cervical spinal nerves reaching the diaphragm below. It is emphasized that eighth spinal nerve does not join this union.

The sixth cervical spinal nerve leaves from the hole between the fifth and sixth vertebrae by separating into two branches similar to third, fourth, and fifth cervical spinal nerves. The one of these nerves go upward and distributes to the head, muscles of the back, and the pelvic bone.

The seventh cervical spinal nerve leaves from the hole between the sixth and seventh vertebrae by separating into two branches. One of the branches travels to the diaphragm joining branches from the fifth and sixth spinal nerves. The other branch joins some of the branches from the sixth and eighth spinal and first thoracal spinal nerves.

The eighth cervical spinal nerve leaves from the hole between the seventh cervical vertebra and the first thoracic vertebra. Some of the branches of this nerve travel to the head and the neck; some of the branches travel to the shoulder, arm, wrist, hand, and the palm. Sixth cervical spinal nerve reaches the scapular region while the seventh cervical spinal nerve reaches the arm.

İtâkî described the cervical spinal nerves more in detail than the other spinal nerves. He described the number of cervical spinal nerves and emerging holes correctly. He defined that the first two cervical spinal nerves only have one branch each while the other cervical spinal nerves have two branches. He defined that the eighth cervical spinal nerve had two separate nerve fibers correctly, but he could not describe the location of separation into two different branches. He did not describe where the first cervical spinal nerve exited from the spinal cord; however, he described the exit points of the other cervical spinal nerves correctly. Most of his descriptions regarding the targets of the cervical spinal nerves were described 
incorrectly. However, most of the information provided for the first cervical spinal nerve was correct.

İtâkî defined the phrenic nerve, which goes to diaphragm. However, the information about the phrenic nerve forming from the fifth, sixth, and seventh cervical spinal nerve is incorrect.

It is told that the nerves leaving from the spinal cord go to target organs by making small connections. We believe that the information was mentioned by İtâkî about the small connections are plexuses. However, in the cervical spinal nerves section, cervical plexus was not mentioned. It was told that only some of the branches of the fourth and fifth cervical nerves formed connections and the union of these nerves are quite small. İtâkî described that some nerve fibers originating from the sixth, seventh, and eighth cervical spinal nerves and first thoracal spinal nerve united and travelled to the upper extremity. We believe that the brachial plexus was described almost correctly.

\section{Thoracal spinal nerves}

İtâkî defined 12 thoracal spinal nerves.

The first thoracal spinal nerve exists through between the first and second thoracic vertebrae and then branching into two. The larger first branch travels to the muscles between the ribs. The second branch rises above the ribs and, as told in the cervical spinal nerves section, it merges with the branches of the sixth, seventh, and eighth cervical spinal nerves.

The second thoracal spinal nerve exists between the second and third thoracic vertebrae branching into two. One branch gets the sensory information from the skin of the arm the other branch travels to the hand.

İtâkî did not analyze the rest of the thoracic nerves separately, but he correctly described the point of exit from the corresponding vertebrae. He described that branches of these nerves innervated the muscles between the ribs, hand, and scapular sides. He described the arteries and veins accompanying the nerves innervating the muscles between the ribs.

İtâkî described the first two thoracal spinal nerves in detail while he described the rest in lesser detail. We believe that İtâkî correctly described the branch of the first thoracal spinal nerve which innervates the intercostal muscles is intercostal nerve. However, he was incorrect when he described that this nerve innervates the muscles of the back. He correctly described that the other branch of the first thoracic nerve joined the brachial plexus innervating the upper extremity. İtâkî defined the branch of the first thoracal spinal nerve travelling to the wrist. We believe that he probably considered the anterior ramus of the first thoracal spinal nerve, inferior trunk, medial fascicle, and ulnar nerve as a single structure.

We think that the sensory branch innervating the skin of the arm was intercostobrachial nerve originating from the second thoracal spinal nerve. However, we currently know that the other branch of the second thoracal spinal nerve does not innervate the hand as he previously stated. Today's knowledge tells us, hand and scapula are not innervated by the second thoracal spinal nerve.

\section{Lumbar spinal nerves}

İtâkî described the lumbar region as the strap bearing region, and he defined five couples of nerves originating from this region. These nerves are divided into three branches; the first one travelled to the back, second branch travelled to the anterior muscles of the abdomen, and the other branch travelled to the muscles of the back. The first three lumbar spinal nerves were defined to merge with the nerves descending from the brain. A small part of the third lumbar spinal nerve and larger parts of the fourth and fifth spinal nerves united with the nerves of the sacrum and the coccyx. He told that the union of this nerve bundle reached the coccyx area, inguinal region, knee, and the calf regions.

We believe that İtâkî could have described the connection of the spinal nerves with the sympathetic trunk by describing the union of the first three lumbar spinal nerves with the nerve coming from the brain. We believe that he described the formation lumbosacral trunk because of the forming of the union of a small part of the third lumbar spinal nerve and larger parts of the fourth and fifth spinal nerves united with the nerves of the sacrum and the coccyx. However, the forming of the lumbosacral trunk explained incorrectly by coming from a small part of the third lumbar spinal nerve and joined to it.

İtâkî stated that the nerve was formed by the fusion of the branches of the third, fourth, and fifth spinal nerves course to the coccyx area, inguinal region, knee, and the calf regions. We believe that the sacral plexus is formed by the lumbosacral trunk and nerves coming from sacrum and coccyx. According to innervation area, we think that the sciatic and tibial nerves which are the branches of the sacral plexus were also identified.

\section{Sacral and coccygeal spinal nerves}

Six couples of sacral and coccygeal spinal nerves were defined. First three spinal nerves were defined as originate from sacrum. The origins of the last three nerves were untold. It was told that the first nerve united with other nerves coming from above and travelling to the calf region. The second and the third nerves went to the coccyx area. He told that the course of the last three nerves travelled to the penis, bladder, and the anus. In addition, apart from these six nerves, he defined a single nerve originating from the coccyx. Although not completely accurate, we think that İtâkî mentioned the sacral plexus and the pudendal nerve. 
In the most detailed drawing (Fig. 1) about the spinal nerves in the manuscript, the emerging of the first left thoracal spinal nerve from vertebral column was demonstrated more inferior placement. The right second thoracal spinal nerve was not shown. The drawing of the number and emerging place of the other spinal nerves was compatible with the manuscript. The plexus structures were not shown in the figure.
"Teşrih-ül Ebdan ve Tercümânı Kıbale-i Feylesûfan" which was printed in the 17th century has seven different editions surviving today. Some editions had been reprinted in the 18th century making us to believe that it had been a commonly used textbook in medical education in the Ottoman Empire. The author had observed Western and Islamic medical authorities at the time, combining them with his own experience $[4,7]$. At the introduction part of the manuscript, God
Fig. 1 The drawing about the spinal nerves in handwritten (Hüsrev Pașa 464, from the Collection of the Suleymaniye Library Istanbul, Turkey)

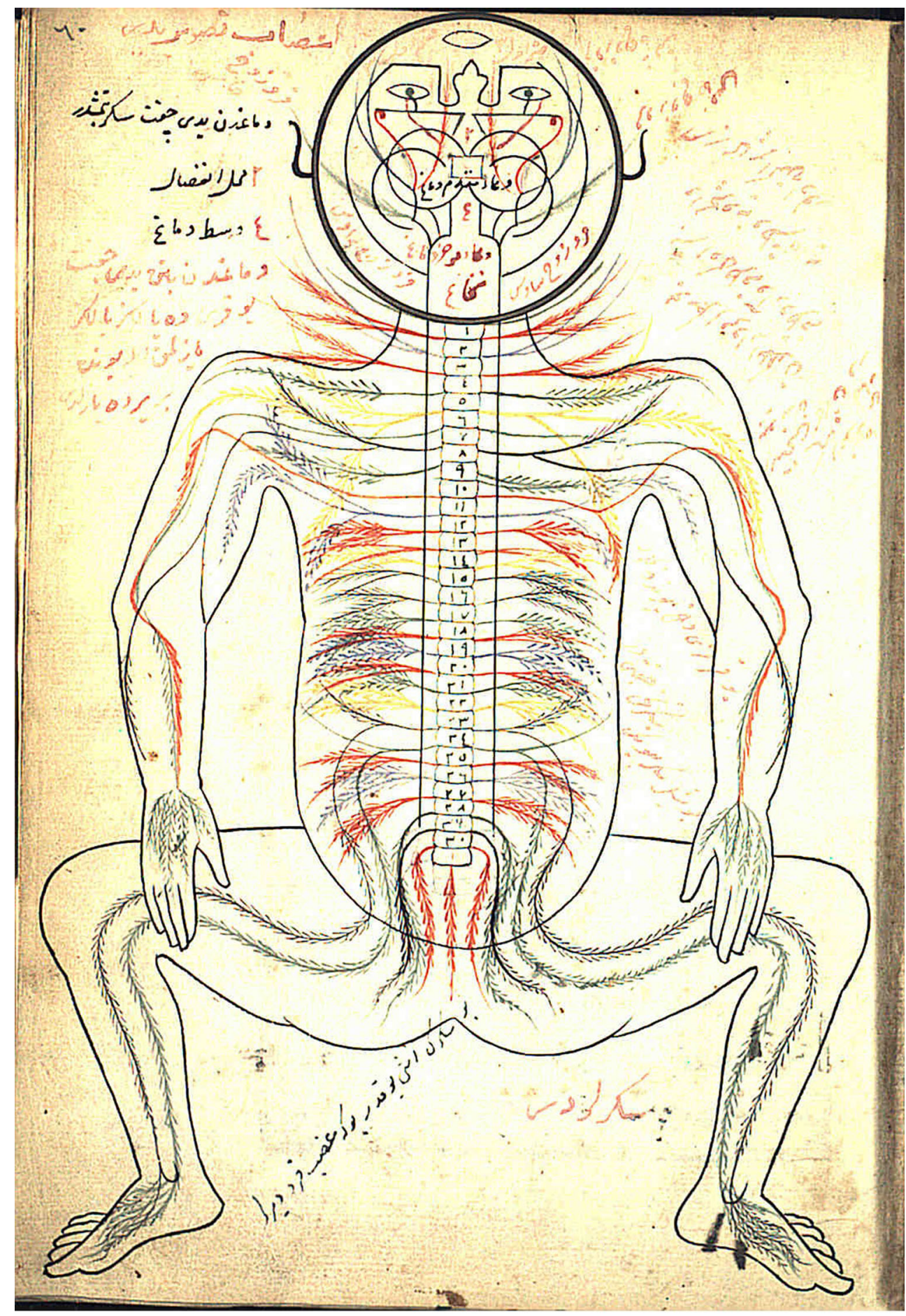


was praised as seen in the other books printed in the era and throughout the book some theological explanations were provided as well.

İtâkî defined some of the anatomical structures in comparison with the animal anatomy. Since human dissection was not common during the 17th century Islamic world, we believe that the author had performed dissections on animals than applied his knowledge to human body. Some anatomical parts were described in detail. We believe that it is a result of the high rates of wars helping the doctors observes many anatomical parts in detail.

İtâkî correctly guessed the number of cervical, thoracic, and lumbar spinal nerves. However, he stated that sacral and coccygeal spinal nerves consist of six couple nerves and one single nerve. The description of 31 spinal nerve couples is consisted with our current knowledge. However, emergence of a single nerve from the coccyx in addition to 31 couples of nerve is not correct. Ulucam et al. [11] reported that the one nerve exiting the coccyx could be filum terminale. However, we do not think that this nerve could be the filum terminale located in the vertebral canal.

Şemseddîn-i İtâḳ̂̂s “Teşrih-ül Ebdan ve Tercümânı Kıbalei Feylesûfan" has an important role in the history of anatomy. It had huge impact in the development of anatomy in the Ottoman Empire, and it was widely used for medical education. In spite of lack and the presence of incorrect information, we believe that it played an important role in the development of anatomy. In addition to these, we believe that this type of works must be analyzed with future research in order to shine a light to the scientific history of Anatolia.

\section{Compliance with ethical standards}

Conflict of interest The authors declare that there is no conflict of interest.

\section{References}

1. Ferit D (2000) Osmanlıca-Türkçe Ansiklopedik Lügat. Aydın Kitabevi Yayınları, Ankara

2. Çıkmaz S (2006) Türkçe anatomi terimlerinin etimolojik ve semantik açıdan incelenmesi. (Doktora Tezi), Edirne: Trakya Üniversitesi, 2006: 16

3. Adıvar A (1982) Osmanlı Türklerinde İlim. Remzi Kitabevi, İstanbul

4. Kâhya E (1996) Şemseddîn-i İt kî’nin Resimli Anatomi Kitabı. Ankara Kültür Merkezi Yayınları, Ankara

5. Akar M (2015) Cerrahi tekniklerin resimsel anlatımı. Art-Sanat: 1545

6. Akdoğan I (2008) 17. Yüzyılda Avrupa'da ve Osmanlı Devletinde Anatomi. Türkiye Klinikleri J Med Ethics-Law Hist 16:166-170

7. Bayat AH (2010) Tip Tarihi. Merkezefendi Geleneksel Tıp Derneği, Ankara

8. Kâhya E (1988) Türkiye Diyanet Vakfi İslam Ansiklopedisi. Türkiye Diyanet Vakfi Yayın Matbaacılık, İstanbul

9. Kâhya E, Bilgen B (2014) Kitab-1 Teşrihü'l-ebdan min e't-tıb. Atatürk Kültür Merkezi, Ankara

10. Turgut M (2008) Șemseddin-i Itaki's contributions to neuroanatomy and embryology in the seventeenth century. Childs Nerv Syst 24:1281-1282

11. Ulucam E, Mesut R, Gökçe N (2005) Neuroanatomy in Tesrih-i Ebdan: a study on a book which is written in Ottoman era. Neuroanatomy 4:31-34 